\title{
LSPベクトルVCV規則音声合成方式のための 合成単位素片数と素片選択法
}

\author{
正貝清 水忠 昭（鳥取大学） \\ 正員吉 村 宏 紀 (大阪府立大学) \\ 非会員西田博 充( 鳥取大学) \\ 非会員井須 尚 紀( 鳥取大学) \\ 正員菅田一博（鳥取大学）
}

\section{Determination of Dictionary Size and Selection Rule for Speech Synthesis based on LSP Vector VCV Method}

Tadaaki SHIMIZU (Tottori University), Hiroki YOSHIMURA (Osaka Prefecture University), Hiromitsu NISHIDA (Tottori University), Naoki ISU (Tottori University), Kazuhiro SUGATA (Tottori University)

\begin{abstract}
This paper argued the number of VCV instances to be recorded in the synthesis unit dictionary as well as selection methods for small scale speech synthesis system. We proposed two selection methods, i) selection method by using phonemic environmental resemblance score (PER method), ii) selection method by searching minimal LSP distance path (MLD method). We evaluated synthesized speech generated by these methods. The followings were clarified, a) improvement in quality of synthesized speech was saturated with $14,000 \mathrm{VCV}$ instances. b) There was scarcely any difference in quality of synthesized speech between PER method and MLD method through the subjective comparison test.
\end{abstract}

キーワード：規則合成, ベクトル量子化，LSP分析，VCV単位

\section{1.まえがき}

日本語の規則音声合成では，子音と母音を組み合わせた 音声素片を合成単位とする合成方式が各種提案されてい る。合成音声の高品質化をめざして，CV単位に基づく合成 方式(1)から，CV-VC単位を用いる方式(4)や，VCV単位(5)や $C V C$ 単位(6)を用いる方式へと，上り長い合成単位を用いる方 式が提案されてきた。さらに，CVCV単位にまで選択範井 を㕕げて合成単位のセットを検討する研究(7)や，様々な合成 単位を選択的に用いる合成方式の研究(8)も行われている。一 方，合成単位をVCVなどの比效的短い単位とし，同一の合 成単位に対して様々な音韻環境を持つ複数の素片を保持す ることで，合成音声を高品質化する万法もとられている。 ${ }^{(9)}$

これら合成音声の高品質化を目ざす研究において，合成 音声を生成するために合成システムが保持すべき合成単位 辞書の記憶容量は增加してきた。特に，近年盛んに研究さ れている波形重盢方式では，合成単位を音声の分析パラ メータではなく，時間波形の形で記憶するため合成単位辞 書の記憶容量は非常に大きい。小山らによるVCVを基本単
位とする波形規則合成方式(9)では，合成単位辞書に60Mバイ トの記憶容量を要することが報告されている。

少ない情報量で，高品質な音声合成を行うために，麻生 らによって音声素片デー夕を記録するパラメータにベクト ル量子化学適用する手法が特許出願されている(10)。我々 は，小規模な応用に対して高品質な合成音声を与えるため に，音声を記録するパラメータとしてLSPパラメータを用 い，LSPベクトルVCV規則音声合成方式の開発研究を続け てきた。LSPベクトルVCV規則音声合成方式では，合成単 位辞書の記録方法にベクトル量子化(11)尊入することで， 様々な音䫓環境から採取した多くのVCV素片を少ない記憶 容量で記憶できる。これにより，小規模な音声合成システ ムでも合成音声の品質を向上できる可能性が高いのが特長 である。(12)-1441

LSPベクトルVCV規則音声合成方式では，1Mバイトから $4 \mathrm{M} ハ$ ハト程度の合成単位辞書で高品質な合成音声を生成す ることを目標にしている。本論文では，LSPベクトルVCV 規則音声合成方式の奏現に向けて，合成単位辞書に収録す る合成単位素片の適正な数とその選択方法を実験的に検証 
した。合成単位素片の選択法として，(i)本論文で定義した 音韻環境類似度スコア(PERスコア)を用いて合成単位素片の 音韻環境を最適化する方法と，(ii)合成単位素片接続部にお ける接続昰みを最小化するMLD選択法について検討した。

ニュースの読み上げ音声から採取した様々な音韻環境に おけるVCV素片を合成単位素片として用い，上記の2つの方 法によって作成した合成音声の品質を主観評洒実験により 評価した。音声合成に用いるVCV素片の数を增加させる と，どちらのVCV素片選択法を用いても合成音声の品質は 向上するが，品質の问上はVCV素片の数が14,000個程度に なると飽和することが判明した。また，どちらのVCV素片 選択法を用いても合成音声の品質には差がなかった。ま た，本方式において，LSPパラメー夕に対してベクトル量子 化を適用した場合，代表べタトル数を27個以上とすれば，ベ クトル量子化を行わない場合に比べて，合成音声の品質劣 化が小さいことを予備実験により確かめている(14)。この結 果に従えば，14,000個程度のVCV素片は，256Kバイト程度 で合成単位辞書に格納でき，コードブックや駆動音源辞書 を合わせても1Mバイト程度の記憶容量で記録できる。本力 式でLSPパラメータに適用したベクトル量子化に関する実験 の詳細については，すでに報告している(14)。合成単位素片 の選択法に関しては，PERスコアによる選択法は処理速度 は速いが合成単位素片の音韻睘境を記憶しておく必要があ るために合成単位辞書の記憶容量が増之る。一万，MLD選 択法は動的計画法(DP)の手法を使用するため速度は荤い が，合成単位辞書の記憶容量は小さい。奏験により，両者 の間に合成音声の品質に差がないことが判明したため，記 憶容量の削隇を重要視している本方式では，MLD選択法を 用いてVCV素片の選択を行えば良いことが判った。

\section{VCV合成単位}

〈2・1〉音韻の取り扱いとVCV素片 本論文で述べる寒 験では，音声資料に視察で音韻マーキングを施して使用し た。日本語における音韻の種類や数には，諸説がある。本 研究では，音韻の種類と表記に関しては原則的に斎藤(15)の 分類に従い，外来語の音節表記(ウィ，ヴァ等)に対応する外
来語音韻は取り扱わなかった。また，VCV音声合成を簡便 に行うため，半母音，拗音，はつ音については特に以下の 取り扱いした。半母音 $\mathrm{S}(\mathrm{j} / \mathrm{j} / \mathrm{w} / \mathrm{w})$ を子音Cとして扱い，捌音 節を作る CS $(/ \mathrm{kj} /$ / / sj/等)を一つの子音として扱った。このた め子音数は26種である。標潐的な日本語5母音の他，はつ音 N/を母音と同様に扱ったため，母音は6種類となる。また， はつ音 $/ \mathrm{N} /$ は，次に続く音韻によって様々に発音さ机ること から，VCV規則音声合成システムでは4つ程度に分類して扱 うことが多い。しかし，本研究の音声合成系では，同じ VCV合成単位に属する素片を様々な音韻環境から複数切り 出して使用するため，はつ音を複数に分類することはしな かった。これは，音声合成時の合成単位素片の選択におい て適切なはつ音を含む合成単位素片が選択されることを期 待しているためである。

合成単位としては，母音で子音を挟む形のVCV型570種 類，子音を挟まないVV型35種類, 語頭用の\#CV型95㮔類と \#V型5種類, 語尾用のV\#型6種類がある。以後, これらの型 の合成単位を棇称してVCV合成単位(VCV unit) と呼び，それ ぞれのVCV合成単位の素片データをVCV素片(VCV instance) と呼ぶ。

〈2・2〉合成単位辞書と合成単位の収集 本研究では, 小型であることや安価であることが求められるカーナビ ゲーション等の音声合成や医療器具等での文書の読み上げ などを考慮して，標準的な日本語発話の合成を対象とし た。このため，標準的な日本語と考えられるNHKアナウン サの発話を塞験に用いた。また，実験では新聞の報道記事 の読み上げを行うため，NHKのFMラジオ・ニュースをを合 成単位の収集に用いた。合成単位辞書に収録するVCV素片 は, NHKのFMラジオ・ニュースの男性アナウンサの発話部 分に梘察で音韻マーキングした資料を用いて，母音部の中 間点で切り出す方法で自動的に生成した。VCV素片の収集 に使用した音声資料は，1997年8月6日から9月25日までに放 送された7日分のFMラジオ・ニュースから切り出した同一 の男性アナウンサの発話部分である。男性アナウンサの発 話部分は，FMラジオ・ニュース1日分で約10分間あり，合 計 70分間の音声資料となる。音声資料は，標本化周波数

表1 音声資料の長さと採取された VCV単位の種類数, $\mathrm{VCV}$ 素片の数

Table 1. The numbers of VCV units and VCV instances due to length of speech data

\begin{tabular}{|c|c|c|c|c|c|c|c|c|c|c|c|c|}
\hline \multirow{2}{*}{$\begin{array}{c}\text { 音声資料 } \\
\text { の長さ }\end{array}$} & \multicolumn{2}{|c|}{ VCV型 } & \multicolumn{2}{|c|}{ VV型 } & \multicolumn{2}{|c|}{ \#CV型 } & \multicolumn{2}{|c|}{ \#V型 } & \multicolumn{2}{|r|}{ V\#型 } & \multirow{2}{*}{ 棇種類 } & \multirow{2}{*}{$\begin{array}{l}\text { 素片 } \\
\text { 数数 }\end{array}$} \\
\hline & 種類 & 平均個数 & 種類 & 平均個数 & 種類 & 平均個数 & 種類 & 平均個数 & 種類 & 平均個数 & & \\
\hline (is) & 341 & $7.7^{\text {(用) }}$ & 29 & $19.3^{\text {(值) }}$ & $52^{(16)}$ & $6.5^{\text {(Nㅏㄴ) }}$ & $5^{(\text {(16) }}$ & $20.8^{(\mid(1) t)}$ & $6^{(\text {(柇) }}$ & $73.5^{\text {(陑) }}$ & 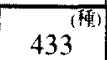 & $\begin{array}{l}\text { (1/2) } \\
4.050\end{array}$ \\
\hline 20 & 400 & 12.5 & 31 & 36.7 & 64 & 9.7 & 5 & 35.8 & 6 & 134.0 & 506 & $\overline{7,759}$ \\
\hline 30 & 429 & 17.2 & 35 & 48.9 & 65 & 11.0 & 5 & 41.6 & 6 & 152.8 & 540 & 10,926 \\
\hline 40 & $\overline{446}$ & 21.4 & 35 & 61.4 & 67 & 11.6 & 5 & 48.2 & 6 & 169.1 & 559 & $\overline{13,713}$ \\
\hline 50 & 455 & 27.4 & 35 & 81.2 & 73 & 15.6 & 5 & 68.6 & 6 & 246.5 & 574 & $\overline{18,271}$ \\
\hline 60 & 466 & 32.7 & 35 & 98.2 & 76 & 20.2 & 5 & 88.6 & 6 & 328.5 & 588 & 22,622 \\
\hline 70 & 470 & 38.4 & 35 & 177.1 & 78 & 21.5 & 5 & 101.2 & 6 & 362.7 & 594 & 26,517 \\
\hline 可能な種類 & 570 & & 35 & & 95 & & 5 & & 6 & & 711 & \\
\hline
\end{tabular}

注）\#は無音を表しており、殃V型と\#V型は発話開始点に、V\#型は発話終了点に用いる。 
$11.025 \mathrm{kHz}$ ，量子化数16ビットでサンプリンダした。採取し たVCV素片は, フレーム長256点, インターバル64点, 次数 12次でLSP分析した。また，収集されたVCV素片には，子 音開始点と後部母音の開始点を示す情報を付加した。

表 16 ，音声資料から採取したVCV合成単位の種類数と， 各々のVCV合成単位に属するVCV素片の数の平均值を示 す。音声資料に含まれるVCV素片が全てのVCV合成単位を 網羅していないため，表1のVCV合成単位の種類数は，〈2. 1)で述べたVCV合成単位の種類数に達していない。音声合 成時には，合成単位辞書に収録されていないVCV合成単位 は，子音上後続母音の一致する他のVCV合成単位加ら先行 母音の部分を除いて作成されるCV合成単位によって代用す る。この際，先行母音部は補間によって作成する。

\section{3. 音声合成システム}

$\langle 3 \cdot 1\rangle$ 音声合成システムの概要ＬSPベクトルVCV規 則音声合成方式による音声合成システムのブロック図を图1 に示す。音声合成システムは，入力された所望の文章の文 字列妾, 音韻列を経てVCV 合成単位の系列に変換する。 VCV 合成単位の系列に従って，合成単位辞書にベクトル量 子化されたLSPパラメータの形で記録されているVCV素片 を選択し接続することにより，代表べクトルのインデック ス系列を得る。得られた代表バクトルのインデックス系列 は，コードブックを参照することにより，所望の文章を合 成するためのLSPパラメー夕系列に变換される。一方, $\mathrm{VCV}$ 合成単位の系列に従って，代表残差波形辞書を用いて 駆動音源信号を生成する. 生成されたLSPパラメータ系列と 駆動音源信号を用いてLSP合成することで合成音声を得る。

合成単位辞書には同一のVCV合成単位に属する VCV素片 が多数收録されて扔り，同一の文章を作成する場合でも可 能なVCV素片の組み合わせが多数存在する。高品質な合成 音声を得るためには，充分な数のVCV素片デー夕を合成単 位辞書に収録するとともに，適切な $\mathrm{VCV}$ 素片を選択し接続 することが必要である。本論文では，LSPベクトルVCV規

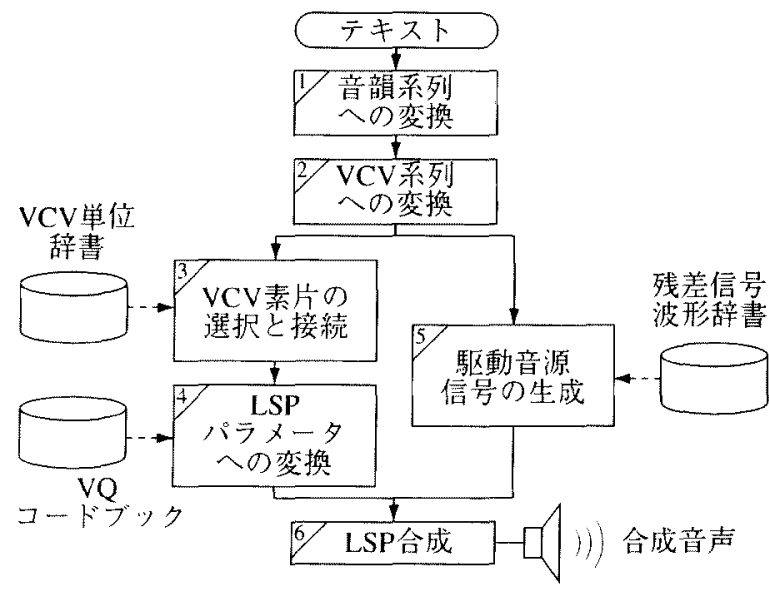

図1 音声合成システムのブロック图

Fig.1. Block diagram of the speech synthesis system
則音声合成方式の実現に先立って, ベクトル量子化を行っ ていない合成単位辞書を用いて，合成单位辞書に収録する VCV素片数とその選択方法について実験的に検証した。 $\mathrm{VCV}$ 素片の選択法として, (i) VCV素片を収集した際の音韻 環境と合成する文章中での VCV 素片の音韻環境の類似度を 素片選択の基準にする方法と，(ii) VCV素片の接続部での接 続歪みを素片選択の基準にする方法の2種類を検討した。

以下の実騒は，全てベクトル量子化を行っていない合成 单位辞書を用いて行ったが，(i)の選択法による素片選択は ベタトル量子化の有無を問わず同じ選択結果となる。(ii)の 選択法では，ベクトル量子化によって生じる量子化䛊差に より,ベクトル量子化の有無によって絜片の選択結果に違 いが出石可能性がある。しかし，先に述べたように，本方 式に扔いて，LSPパラメータのベタトル量子化による合成音 声の品質劣化が小さいことを予備奏験により確かめてい る。これは, ベクトル量子化による誤差が, 最適な接続の 場合の素片の接続歪みに比べて十分小さいことを示唆して おり，ベクトル量子化を適用することにより選択法に関す る害験結果に大きな影響を及ばさないと考えられる。ベク トル量子化を適用した場合の詳細な検討扔よび選択法の改 良に関しては，すでに報告している(14)。

〈3.2〉音韻瑾境の類似度によるVCV素片の選択法 合 成素片の選択の際に音韻環境を考慮する方法は多数提案さ

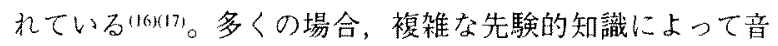
韻環境の適応度を算出する方法がとられているが，本研究 では簡便性を考虑して，音韻環境の類似度を得点化する方 法をとった。VCV素片を収集した際の音韻環境と所望の文 章中での VCV素片の音韻環境の類似度を評洒するために, 図2に示すようにVCV素片の前後5つずつの音韻を考虑し， 式(1)の音韻環境類似度(Phonemic Environmental Resemblance Score: PERスコア)定義した。

$$
\text { PER }=\frac{1}{2} \sum_{i=1}^{5} \frac{1}{3^{i}}(f(i)+r(i))
$$

ここで, $f(i)$ はCV素片の先行する $i$ 番目の音韻につい て、VCV素片を収集した際の音韻と合成する文章中での音 韻の一致度を表す音韻得点である。 $f(i)$ には，音韻が一致す

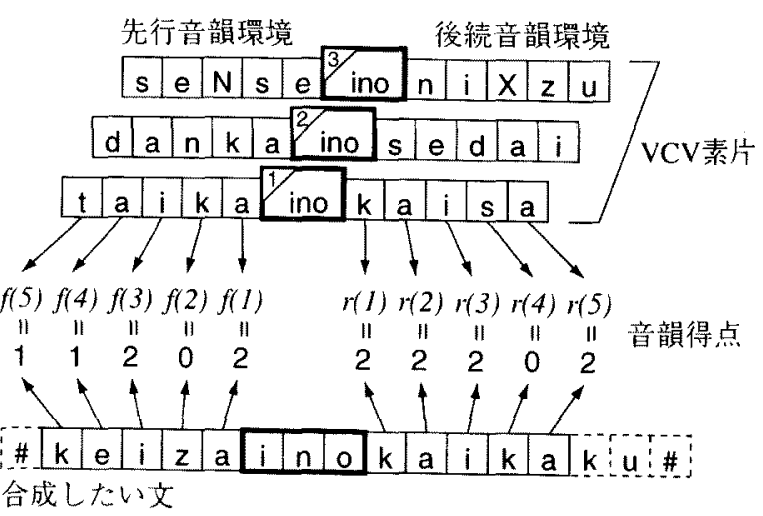

図2 PERスコアによる音韻環境の得点化

Fig.2. Point rating of phonemic environment on PER score 
れば2点，母音，摩擦子音，破裂子音等の音韻種別が一致す れば1点を与え, どちらも一致しない場合には0点を与え る。r(i)はVCV素片の徯続するi番目の音韻についてのf(i) と 同様な得点である。 $f(i)$ とr(i)をVCV素片の前後それぞれ5つ の音韻について時間経過を考慮した重み付きで合計したも のをPERスコアとしている。音韻得点の重みは, VCV素片 により近い音韻得点の差が，より遠い音韻得点の差によっ て逆転されないように，3の指数の逆数としている。

PERスコアによるVCV素片の選抧法では，合成単位辞書 にはVCV素片のデータだけでなく、VCV素片の音韻環境の 情報として素片の前後5つの音韻名を記憶しておく。音声合 成時には，音韻環境の情報と所望の文章中でのVCV素片の 音韻環境を用いて式(1)で定義したPERスコアを計算し， PERスコアが最大となるVCV素片を選択寸る。

〈3・3〉接続䄳みの最小化によるVCV秦片の選択法 $\mathrm{VCV}$ 素片の接続部における接続歪みを評価するために， LSPパラメータの距離を用いる。VCV素片の接続部におけ る先行 VCV素片の最終フレームのLSPパラメータが $\boldsymbol{\omega}^{f}=\left(\omega_{l}^{f}, \omega_{2}^{f}, \cdots, \omega_{p}^{f}\right)$, 徯続VCV素片の先頭フレームのLSP パラメータが $\boldsymbol{\omega}^{r}=\left(\omega_{1}^{r}, \omega_{2}^{r}, \cdots, \omega_{p}^{r}\right)$ であるとき，VCV素片 の接続部におけるLSPパラメー夕の距離(LSP distance: LD)を 式(2)で定義する。

$$
L D\left(\boldsymbol{\omega}^{\prime}, \boldsymbol{\omega}^{\prime}\right)=\sqrt{\sum_{i=1}^{p}\left(\omega_{i}^{f}-\omega_{i}^{\prime}\right)^{2}}
$$

接続歪みは，様々なパラメー夕による評洒が可能である が, 本方式ではVCV素片をLSPパラメータの系列として扱 うため，LSPパラメー夕の距離を用いることが奏用的であ b。

式(2)で定義したLD $\left(\boldsymbol{\omega}^{f}, \boldsymbol{\omega}^{r}\right)$ を用いてDPの手法により素片 選択を行う手法を, LSP距離最小化選択法(minimal LSP distance method: MLD選択法)と呼ぶ。MLD選択法による $\mathrm{VCV}$ 素片の選択の様子を図3に示す。同一のVCV合成単位 に属するVCV素片が複数存在するため，図中に执いて破線 で示すようなVCV素片の様々な接䊦が可能である。このよ

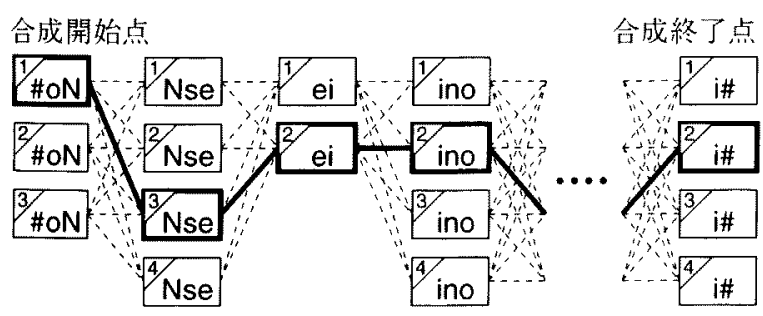

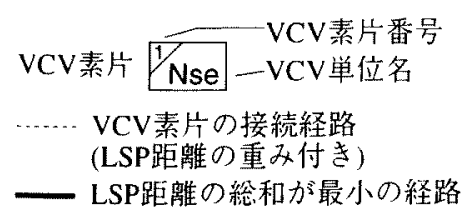

图3 MLD選択法によるVCV素片の選択

Fig.3. Selection rule of VCV instances based on minimal LSP distance method
うに、VCV素片の接続が可能であることを示す経路を接続 可能経路上呼ぶ。MLD選択法は，接続可能経路に式(2)で定 義した $L D\left(\boldsymbol{\omega}^{f}, \boldsymbol{\omega}^{\prime}\right)$ をコストとして割り振り，合成音声の開 始点から終了点までのコス卜の総和が最小となる経路老DP の手法によって探索する方法である。探索の結果得られた LSP距離最小の経路上にある VCV素片を，最適な VCV素片 として選択する。

MLD選択法では，合成単位辞書中のVCV素片デー夕に付 加的な情報を加えておく必要がないため，合成単位辞書の 記憶容量の点ではPERスコアによる選択法に比べて有利で ある。

〈3.4〉 駆動音源 VCV素片を選択し接続するこ上で生 成されたLSPパラメータ系列から合成音声を得るための駆動 音源は，音韻毎に代表残差波形辞書に用意した代表残差波 形を接続して生成する。代表残差波形は，(i)はつ音/ $\mathrm{N} /$ を含 む各寿音については残差信号の1ピッチ分の波形，(ii) 有声 子音については後続母音別に残差信号の1ピッチ分の波形, (iii)無声子音については，後続母音別に無声子音部の残差信 号をLSP分析のインターバル長の整数倍の単位で切り出した 波形である。これらは、VCV素片を採取した音声資料から 得られたLSP分析の残差信号から視察によって切り出した。 図4に，母音/e/の代表残差波形と，後続母音として/o/を持つ 無声子音/k(o)/の代表残差波形を示す。母音/e/の代表残差波 形は, ピッチ周期7.26 msの長さで切り出している。無声子 音/ $\mathrm{k}(\mathrm{o}) / 0$ 代表残差波形は，LSP分析の4インターバル分 $23.22 \mathrm{~ms}$ の長さで，/k/の破裂点老中心して切り出してい 万。

音声合成時には，VCV素片に付加された子音開始点と徭 部母音の開始点の情報に従って代表残差波形を接続する。 有声音の代表残差波形は，所望のピッチ間隔で並べて接続 する。この時，代表残差波形の長さよりピッチ間隔が長い 場合には代表残差波形の後に必要な長さだけ振幅0のデー夕

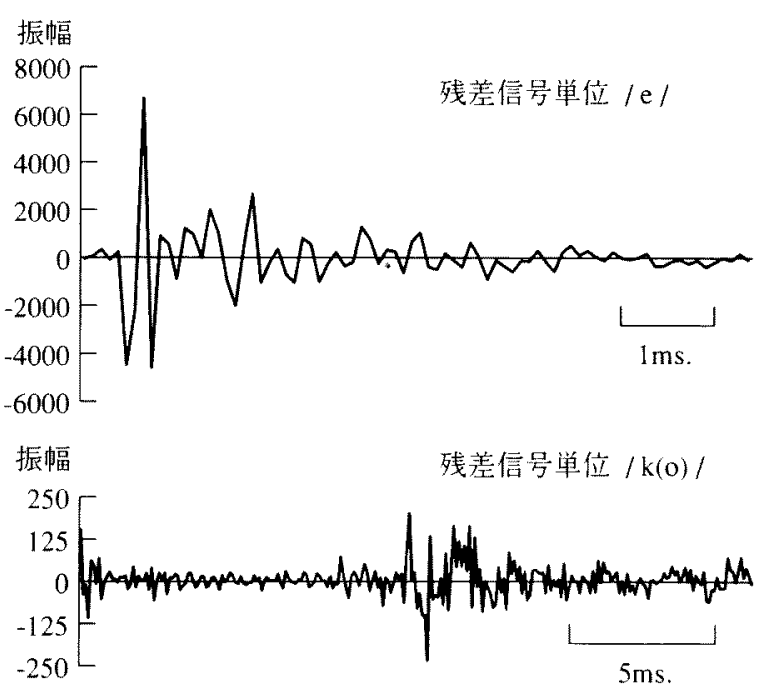

图4 残差信号波形の例

Fig.4. Examples of residual signal waveformes 
在挿入寸る。またピッチ間隔が短い場合には代表残差波 形をピッチ間隔に合わせて打ち切って接続する。無声子音 の代表残差は，VCV素片に付加された子音開始点の情報に 従って適切な位置に挿入する。

\section{VCV素片の選択実験}

〈4.1〉VCV素片の選択実験の方法 合成単位辞書に収 録するVCV素片の適正な数の検証と, VCV素片の選択法の 評洒のために，PERスコアによる選択法またはMLD選択法 を用い，合成単位辞書の大きさをかえてVCV素片を選択寸 る実験を行った。合成単位辞書は，10分から10分きざみで 70分までの長さの音声資料からVCV素片を収集して作成し た7種類の大きさのものを用いた。以後，各々の合成単位辞 書を「合成単位辞書(10)」一「合成単位辞書(70)」のようにVCV 素片を取集した音声資料の長さを付して区別する。各々の 合成単位辞書が収録しているVCV素片の数は，表 1 にCV 素片の総数として示した通り，約4,000個から26,500個であ る。音声合成の対象には見出しを除く新聞記事の本文を用 いた。実験に用いた新聞記事の長さは，VCV合成単位の個 数にして45,269個分の長さである。

自然発話の音声資料から収集したVCV素片によって，音 韻の組み合わせで可能な全てのVCV合成単位を網羅するこ とは困難である。音声合成時に，合成単位辞書に収録され ていないVCV合成単位が必要になった場合には，他のVCV 合成単位の素片からCV素片を作成して代用する。合成単位 辞書に収録されたVCV合成単位の数を評価するために， $\mathrm{VCV}$ 単位網羅率とVCV素片置換率を次のように定義する。

$\mathrm{VCV}$ 単位網羅率は，音韻の組み合わせで可能な VCV 合成 単位の総数を $N, V C V$ 素片の収集で得られたVCV合成単位 の数を勿して，以下のように定義する。

$\mathrm{VCV}$ 単位網羅率： $\gamma=n / N$

$\mathrm{VCV}$ 素片置換率は，合成音声中に含まれるVCV合成単位 の総数をM，そのうちで合成の際にCV素片に固換された

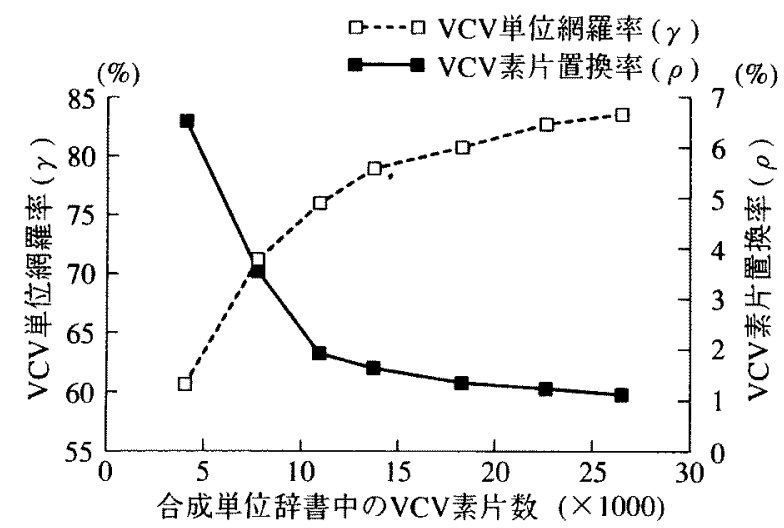

図5 合成単位辞書の規模とVCV合成単位網羅率, $\mathrm{VCV}$ 素片置換率

Fig.5. Covering rate of VCV units and substitution rate of VCV instances
$\mathrm{VCV}$ 素片の数をmとして，以下のように定義する。

$$
\mathrm{VCV} \text { 素片置換率： } \rho=m / M
$$

本実験では, $N=711, M=45,269$ である。

また，実験でのVCV素片選択結果は，(i)合成音声中の $\mathrm{VCV}$ 素片の平均PERスコアと，(ii)合成音声中のVCV素片の 接続部での平均LSP距離で評価した。

$\langle 4 \cdot 2\rangle$ 実験結果図5に, 実験の結果求まった合成単 位辞書の規模と $\mathrm{VCV}$ 単位網羅率, $\mathrm{VCV}$ 素片置換率の関係を 示す。合成単位辞書の規模を大きくする VCV単位網羅率 は向上するが，26,500個のVCV素片を収録した「合成単位辞 書(70)」でも 83.5\%であり，音韻組み合わせで可能なVCV合 成単位の $16.5 \%$ が収録されていない。一方, 合成単位辞書 の規模を大きくするとVCV素片置換率は急激に隇少し，合 成単位辞書のVCV素片の収録数が14,000個以上ではあまり 変化がない。約14,000個のVCV素片を収録した「合成単位辞 書(40)」を用いた場合，VCV単位網羅率は78.9\%と低いが VCV素片置換率は $1.7 \%$ 以下で非常に小さい值である。。こ の結果は，VCV素片の収集にもれたVCV合成単位が音声合 成時に使用される頻度は非常に小さいことを示しており， 合成単位辞書のVCV素片取録数が 14,000 個以上の場合は VCV 単位網羅率の低さが合成音声の品質低下に与える影響 はごく小さいと考えられる。

PERスコアによる選択法とMLD選択法で選択されたVCV

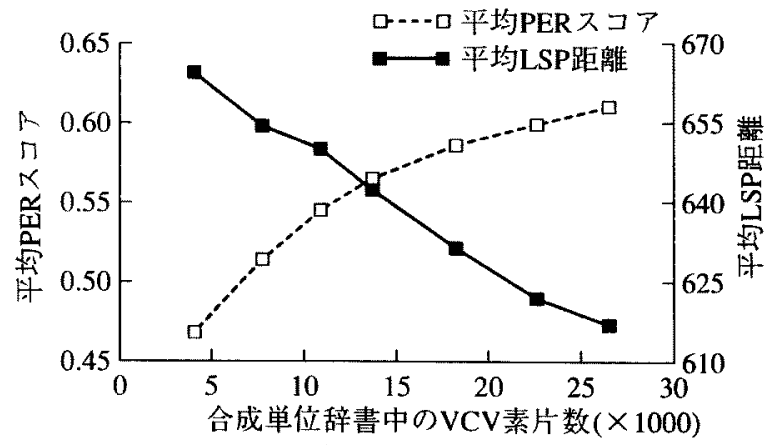

a) PER選択法によるVCV選択

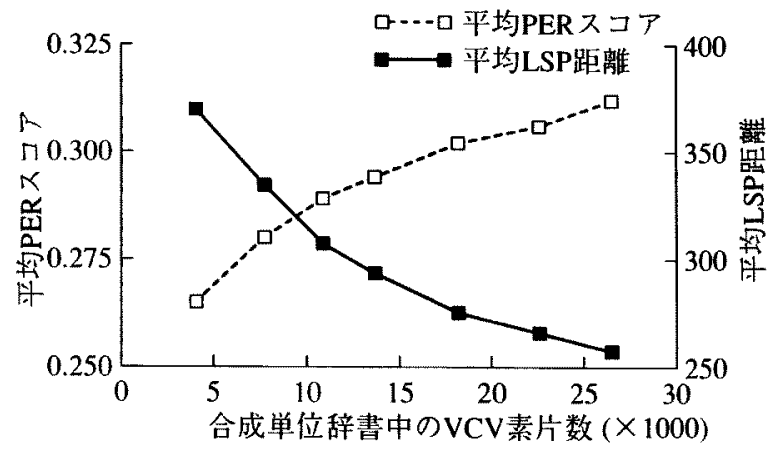

b) MLD選択法によるVCV選択

図6 合成単位辞書の規模と平均PERスコア, 平均LSP距離

Fig.6. Averaged PER score and averaged LSP distance 
素片について，平均PERスコアと平均LSP距離を求めた結果 を図6に示す。PERスコアによる選択方法を用いた場合，合 成単位辞書の規模が大きくなると平均PERスコアは上昇し 平均LSP距離が隇少した。LSP距離最小選択化法を用いた場 合, 合成単位辞書の規模が大きくなると平均LSP距離は減少 し平均PERスコアは上昇した。この結果は，PERスコアによ る選択方法はVCVの接続歪みを小さく抑える傾向があり， LSP距離最小選択化法はPERスコアの高いVCV素片を選択 する傾向があることを示している。しかし，2つの選択法 で，平均PERスコアと平均LSP距離の絶対值は一致していな wo

\section{5. 合成音声の主観評価}

$\langle 5 \cdot 1\rangle$ 合成単位辞書の大きさと合成音声の品質 合成 単位辞書に収録するVCV素片の適正な数を，合成音声の聴 感上の品質の点から検証するために，合成単位辞書の大き さをかえて合成した1対の合成音声のうち「どちらの合成音 声が聞き取りやすいか」の判定を行う1对比較による主観評 価実験を行った。実験には，3秒程度の4つの短文につい

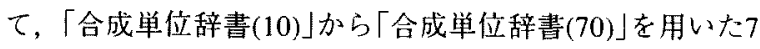
種類の合成音声を合成して用いた。被験者には，7回の練習 比較の後, 合成単位辞書が異なる7種類の合成音声の組み合 わせ21対について順序の入れ替之を含めて8回ずつ168回の1

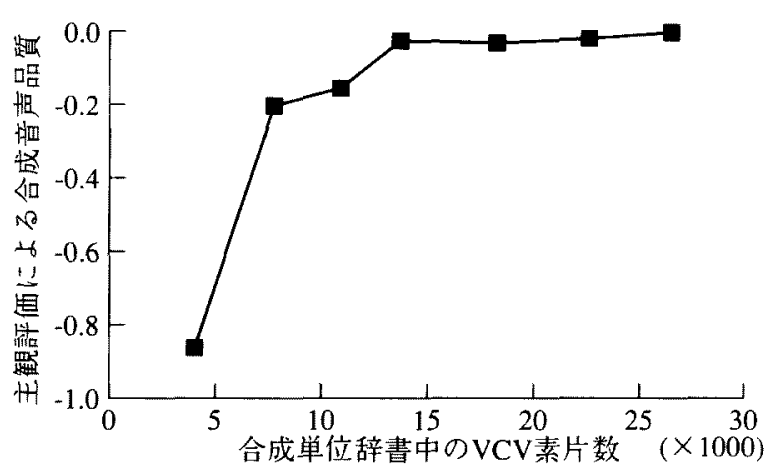

a) PER選択法によるVCV選択

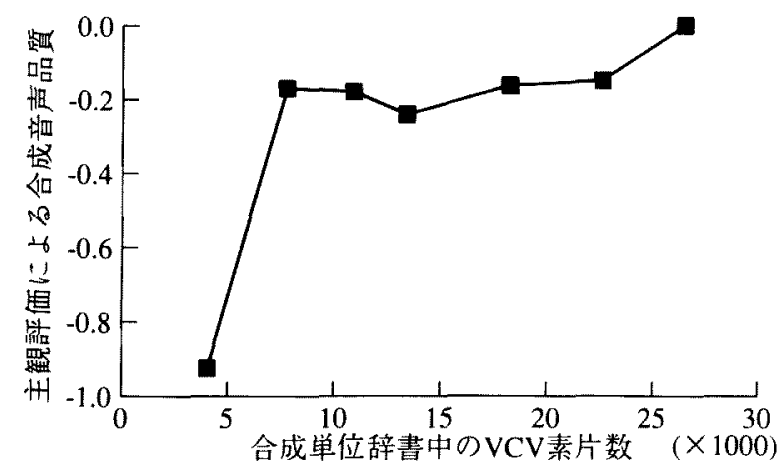

b) MLD選択法によるVCV選択

図7主観評価による合成音声の品質

Fig.7 Perceptual quality of synthesized speech
対比較を課した。比較対の提示順はランダムとし，練習比 較については，そ机が練習であることを被騒者に知らせて いない。

上記の1対比較実験を，PERスコアによる選択法とMLD選 択法による合成音声について行った。PERスコアによる選 択法について被験者は健康な20代の男女11名, MLD選択法 について被験者は煡康な20代の男女10名で実験を行った。1 対比較実験で得られた判定結果から，Thurstoneの比較判定 の法則を用いて，「合成単位辞書(70)」による合成音声を基準 として，合成音声の品質尺度值を求めた。このとき，練習 比較のデータは, 合成音声の品質尺度值は評洒には用いて いない。

実験の結果として，合成単位辞書のVCV素片の収録数と 合成音声の品質尺度值の関係を図7に示す。PERスコアによ る選択法を用いた場合，合成単位辞書に収録するVCV素片 を 14,000 個以上に増やしても，合成音声の品質尺度值は向上 していない。また，MLD選択法を用いた場合，合成単位辞 書に収録するVCV素片を8,000個以上に增やしても，合成音 声の品質尺度值は向上していない。ここに述べた2つのVCV 素片選択法を用いる場合，多くても14,000個程度のVCV素 片を収録した合成単位辞書を用いて音声合成システムを構 築すれば良いといえる。

〈5・2〉VCV素片選択法の比較ＰERスコアによる選択 法とMLD選択法による合成音声の品質の比較のために，1対 比較による主観評洒実験を行った。実娩には，3秒程度の4 つの短文について，「合成単位辞書(70)」を用いて，PERスコ アによる選択法とMLD選択法によって合成した合成音声を 用いた。被験者には，10回の練習比較の後，20回の1対比較 を課した。練習比較についてはそれが練習であることを被 験者に知らせていない。被験者には，此較対の「どちらの合 成音声が聞き取りやすいか」党「同程度である」という評価を 許して判定させた。被験者は健康な20代の男女11名であ る。1対比較実験でより聞き取りやすいと判定された合成音 声に2点，他方に0点を与え，同程度と判定された場合には 雨方の合成音声に1点ずつを与えて，被験者の判定結果を得 点化した。

上記の実験の結果，図8に示すようにPERスコアによる選 択法を用いた合成音声の得点率は53.1\%，MLD選択法を用 いた合成音声は $46.9 \%$ となった。両者の得点について，両側

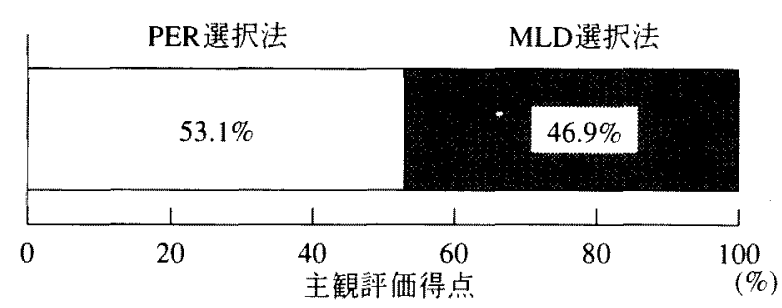

図8 主観評価によるPER選択法と MLD選択法の合成音声の比較

Fig. 8 Subjective comparison in speech quality between PER score method and MLD method 
二項検定を行った結果，有意水準5\%で有意な差はみられな かった。このことから，PERスコアによる選択法による合 成音声とMLD選択法による合成音声の品質には聴感上の差 はないことが判明した。

\section{6. むすび}

本論文では, LSPベクトルVCV規則音声合成方式の実現 のために，合成単位辞書に収録する合成単位素片の適正な 数とその選択方法を実験的に検証した。VCV素片の選択実 験では，14,000個以上のVCV素片を収録した合成単位辞書 を用いた場合, VCV素片置換率はほほ一定の $1 \%$ 程度と非常 に小さい值となった。また，主観評価実験では，14,000個以 上のVCV素片を収録した合成単位辞書を用いた合成音声に は, 聴感上の品質の差がなかった。これより, 合成単位辞 書に収録するVCV素片の数を増加させると合成音声の品質 は向上するが, 品質の向上はVCV素片の数が 14,000 個程度 になると飽和することが判明した。

VCV素片の選択実験では, PERスコアによる選択法と MLD選択法の両者について平均PERスコアと平均LSP距離 は一致していない。しかし, 主観評価実験では, PERスコ アによる選択法を用いた合成音声の得点率は53.1\%, MLD 選択法による合成音声は $46.9 \%$ となり, 両側二項検定を行っ た結果，有意水準 $5 \%$ で有意な差はなかった。これは，PER スコアによる選択法とMLD選択法では, 選択されるVCV素 片は一致しないが, 聴感上の品質は同程度であることを示 している。

PERスコアによる選択法は処理速度は速いが合成単位素 片の音韻環境を記憶しておく必要があるために合成単位辞 書の記憶容量が増える。一方, MLD選択法はDPの手法を使 用するため速度は逑いが，合成単位辞書の記憶容量は小さ い。両者とも合成音声の品質に大きな差がないことが判明 したため, 記憶容量の削減を重要な目標とするLSPベクトル VCV規則音声合成方式では，MLD選択法を用いてVCV素片 の選択を行えば良いことが明らかになった。

従来提案されてきた音韻環境を考慮する方法(8)(9)(16)(17)は, 多くの場合, 複雑な先験的知識によって音韻環境の適応度 を算出する方法がとられている。本研究で述べたPER選択 法は簡便性を考慮して, 音韻環境の類似度を得点化する方 法をとった。実験の結果は, 本研究で扱った合成単位辞書 の規模では，このような簡便な方法でも素片選択の基準と しては十分であることを示している。一方，MLD選択法と 同様な手法は，他の研究でも多く用いられている(9)。しか し，音韻環境基準と接続歪みによる基準の関係は明らかで はない。本研究では, PER選択法とMLD選択法を比較する ことで，VCV素片選択における，音韻環境基準と接続歪み による基準が，異なる選択結果をもたらすが，合成音声品 質には聴感上の差がないことを示した。

(平成11年 1 月 27 日受付, 平成11年 4 月 14 日再受付)

\section{文献}

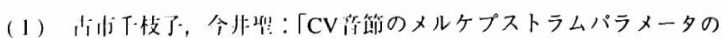

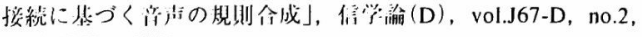
1356-1363, (1984)

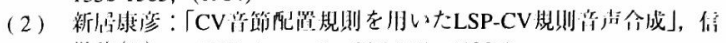
学湔 (A), vol.J70-A, no.5, 836-843, (1987)

(3) T. Minowa and Y. Arai: "The Japanese CV-syllable positioning rule for speech synthesis", Proc. IEEE-IECEJ-ASJ, ICASSP 86, 2031-2034, (1986)

（4）伏林田勝信，二留萃大，佐伯猛，「ホルマントCV-VC)式による 梘則型音声合成システム」, 情報処理学会第3 31 问全国大会落演諭文 集, 1107-1108, (1985)

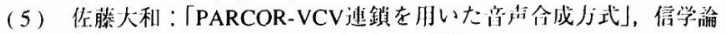
(D), vol.J61-D, no.11, 858-865, (1978)

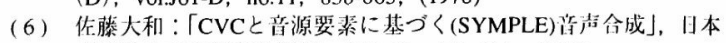

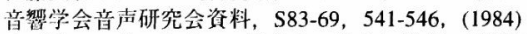

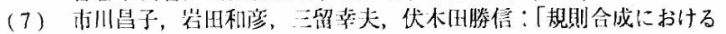
単位音声セットの怡討」, 信学技報, SP87-6, 41-48, (1987)

(8) 武田一哉, 安部勝雄, 何坂芳典：「選択的に命成单位を用いる規則 音声合成」, 信学論 (D-II), vol.J73-D-11, no.12, 1945-1951, (1990)

（9）小山貴夫, 小泉宣夫：「VCVを基本単位とする波形規剘合成少式 の検討」，信学技報，SP96-8，53-60，(1987)

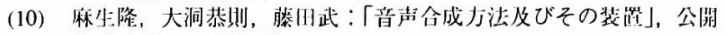
特部公報(A), 特临平5-73100, (1993)

(11) Gersho A. and Cuperman V. : "Vector quantization : A pattern-matching technique for speech coding", IEEE Commun. Mag., 21, 9, 15-21, (1983)

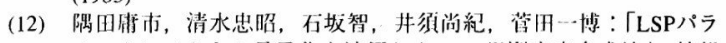
メータにベクトル量子化を適用したVCV規則音声合成泣」, 情報 処理学会第55回全国大会檴演論文集(分湖2)，p.14，(1997)

(13) 西田博充, 清水忠昭, 吉村宏紀, 非须淌紀, 菅目一博, “LSPベク

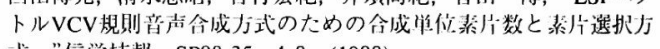
式, ”信学技報, SP98-35, 1-8, (1998)

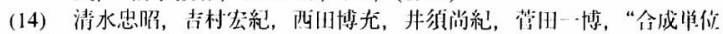

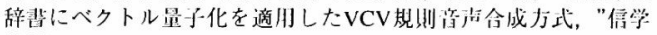
技報, SP98-35, 9-16, (1998)

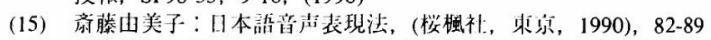

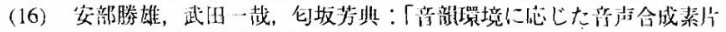

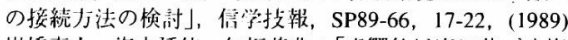

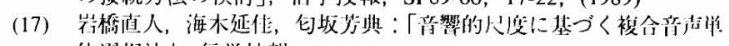

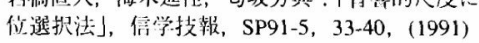

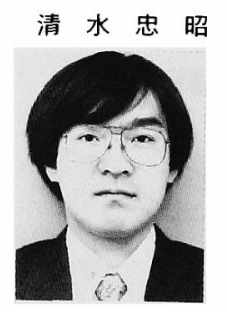

（正員） 1963 年生。1987 年 3 月 大阪大学基礎工 学部生物工学科卒業。同年鳥取大学工学部助手。 音声信号処理, ニューラルネットワークの研究に 従事。電子情報通信学会, 日本音響学会の各会 員。

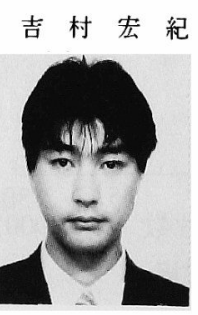

(正員) 1970年生。1998年3月鳥取大学大学院工学 研究科博士後期課程修了。同年, 九州工業大学情 報工学部リサーチアソシエイト。1999年大阪府立 大学工学部助手。博士(工学)。ニューラルネット ワーク, 音声信号処理, ディジタル信号処理の研 究に従事。電子情報通信学会の会員。 
西田博 充 (非会貝) 1998鳥取大学工学部知能情報工学科卒

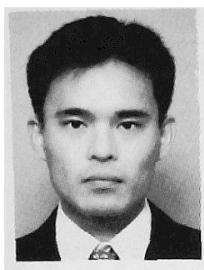

業。現在，鳥取大学大学院工学研究科博士前期渦

程に在学中。音声信号処理の研究に従事。

井須尚 紀 (非会員) 1953 年生。1978 年 3 月大阪大学大学

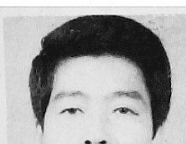
院基礎工学研究科前期課程修了。同年航空宇宙技 術研究所研究員。1 989 福井大·工・電子助教授。 1993 鳥取大·工 · 知能情報助教授。医学博士。動 摇病の生理工学・中枢神経系の生理学などの研究 に従事。情報処理学会, 神経科学学会, 生理学 会, 宇宙航空環境医学会の各会員。

菅田一 榑

（正員） 1938 年生。1966 年 4 月 京都大学大学院 工学研究科博士課程修了。同年 同大電気助手。 1971 年大阪大学基碟工学部助教授。1986 年鳥取 大学工学部教授。工学博士。しきい值論理, オー トマトンと言語理論，計算の複雑さ，音声信号処 理, ニューラルネットワークの研究に従事。電子 情報通信学会, 情報処理学会, 日本音響学会, 人 工知能学会, 日本農業気象学会の各会員。 